\title{
鼻副鼻腔領域の好酸球性炎症について
}

\author{
司会のことば
}

アレルギー性鼻炎の組織で一番目立つ炎症細胞は好酸 球です。好酸球の歴史は長いのに今だにその役割につい ては謎の部分が多い事もよく知られています。当初, 好 酸球は抗原抗体複合物を貪食処理しているのだと考えら れていました。確かにin vitroで好酸球は抗原抗体複合 物質を食食しました。しかし好中球も同じように貪食し たのです。このような状況下で好酸球の研究に一大飛躍 をもたらしたのはGleichでした。彼は好酸球顆粒蛋白 の1つである MBP (Major Basic Protein) の同定に成 功し, この蛋白には上皮障害作用がある事を証明しまし た。1979年のことです。その後 Gleichのグループは膨 大な数の論文を発表し, 好酸球がアレルギー性炎症を引 き起こす主役であるという概念を定着させました。今回 のシンポジウムでは, トップバッターとして鈴木正志先 生にアレルギー性副鼻腔炎の病態，特に好酸球がこの疾 患にどのように関わっているかという点について話して いただきました。アレルギー性副鼻腔炎は最近注目を集 めだした疾患で，好酸球の役割を考える上では興味ある 疾患と考えます。野中学先生には, 好酸球を局所に遊走 させるサイトカインについて発表していただきました。 鼻粘膜と肺より単離した線維芽細胞を用いて, 各種の物 質刺激による RANTES や eotaxin の産生能力を調べたも のです。さて, 局所に遊走した好酸球は決して血中に戻 る事がない事が知られています。そこで好酸球が局所か ら退出する手段はネクローシスかアポトーシスと考えら
獨協医大越谷病院耳鼻咽喉科

*日本医科大学耳鼻咽喉科

渡辺建介, パワンカール ルビー*

れます。渡辺建介はネクローシスの観点から話題を提供 しました。好酸球顆粒蛋白には組織障害性があります が，顆粒蛋白は細胞がネクローシスに陥った時大量に細 胞外に出てくる事を明らかにしました。従って上皮障害 と好酸球のネクローシスは深い関係があると結論されま した。一方, 好酸球がアポトーシスに誘導されれば同じ 細胞死でも細胞膜の破綻はなく細胞が凝縮してマクロフ アージに取り込まれます。従って顆粒蛋白が細胞外へ流 出することもなく処理されることになります。白崎英明 先生には好酸球をアポトーシスに誘導する薬剤について 話をしていただきました。

四人の演者により好酸球が鼻粘膜に遊走し, そして退 出する機序について解明されたと思います。しかし今シ ンポジウムでは好酸球そのものの役割にはあえてメスを 入れませんでした。Gleichにより好酸球はアレルギー 疾患の悪玉の代表として取り扱われてきました。しかし 人間の体のしくみを考えた時，何の益にもならない細胞 が進化の過程で存在し続けるという事は説明しにくい事 です。その意味では好酸球の特異的な仕事は何なのかに ついては全く謎と言っても過言ではありません。最近抗 IL-5 抗体の臨床応用が可能になりました。抗 IL -5 抗体 の投与により好酸球数の減少は証明されましたが，喘息 の症状にはほとんど影響を与えないというショッキング な報告がありました。好酸球の真の役割についてもう一 度原点に帰って考え直す時が来たのかもしれません。 


\section{アレルギー性副鼻腔炎における好酸球浸潤と サイトカイン及びその臨床像}

大分医科大学免疫アレルギー統御講座耳鼻咽喉科学

鈴木 正志

アレルギー性副鼻腔炎が指摘されて十数年が経つが, 末だ本症の病因は必ずしも明らかにはなっていないが, 本症の発症機序として確かにI型アレルギー反応が直接 関与する例のあることが示されている。そこで, 本症に おける好酸球浸潤やこれに関わるサイトカインおよびそ の臨床像について報告した。具体的には，1）臨床的特 徵と好酸球浸潤，2）保存的治療からみたI 型アレルギ 一の関与と好酸球・开イトカイン，3）内視鏡下鼻内手 術の影響についての 3 点である。

\section{1. 臨床的特徴と好酸球浸潤}

アレルギー性鼻炎と副鼻腔炎が同時に見られる症例が 多く, またアレルギー性鼻炎患者の副鼻腔 X 線検査で陰 影出現率が高いことから, アレルギー性鼻炎の副鼻腔炎 への関与, あるいはアレルギー性副鼻腔炎の存在が指摘 されるようになった。本症の病因は, 副鼻腔局所でのア レルギー反応によるものなのか，この場合抗原は自然口 より直接入り込むのか血行性か, 鼻腔でのアレルギー反 応により生じる起炎物質の影響なのか，あるいは自然口 の狭小化や閉鎖による副鼻腔陰圧に関連した炎症性変化 なのか議論がある。これまでのところ，アレルギー性鼻 炎に合併し I 型アレルギー反応が直接的・間接的に関係 する副鼻腔炎というのが，一般的な概念と思われる。

本症の臨床像では, アレルギー性鼻炎の存在が確実で $\mathrm{X}$ 線上副鼻腔陰影の存在することが第一義的であり, 以 下の臨床的特徴がみられる。アレルギー性鼻炎単独例と 比べ, 症状・鼻所見では鼻閉型が多く，下甲介粘膜の腫 脹が強い。粘液性鼻汁であることが多く, 鼻汁や副鼻腔 貯留液中に好酸球はもちろん比較的好中球が多く見ら れ，遅発相が強く影響していることが示唆される。副鼻 腔では起炎物質が停滞しやすく, 鼻腔よりも炎症の遷延 化が窥える。

一方, 非アレルギー性の副鼻腔炎と比較すると自覚的 他覚的いずれの後鼻漏も少なく, 検査所見ではX線検査 上びまん型は比較的少なく粘膜肥厚型やポリープ型を呈 することが多く, 鼻汁の菌検出率が低い。さらに鼻汁や
貯留液の性状が膿性ではないことも重要である。また非 アレルギー性副鼻腔炎に比べ貯留液や粘膜に好酸球や活 性化好酸球が数多く認められ, 好酸球への増殖分化誘導 や活性化作用のある IL-5 や肥満細胞の増殖と, IgE 抗 体産生を誘導する IL-4 がアレルギー性副鼻腔炎の副鼻 腔貯留液に多く検出される。さらに副鼻腔粘膜での特異 抗原による誘発反応が病理組織学的に見られるとする報 告もあり，アレルギー性副鼻腔炎の病因として I 型アレ ルギー自体も十分考えられる。小児においてもその副鼻 腔貯留液や上顎洞粘膜に多数の活性化好酸球の存在が確 認される症例のあることからも，I型アレルギー反応と 直接関係する副鼻腔炎の存在が指摘されている。

\section{2. 保存的治療からみた I 型アレルギーの関与と 好酸球・サイトカイン}

アレルギー性鼻炎患者に存在する副鼻腔陰影に対する 治療法の検討はほとんどみられない。しかし，そのよう な副鼻腔に細菌感染が生じやすいと言われており, 速や かに治療する必要があると考えられる。そこでアレルギ 一性鼻炎が存在し, 鼻汁性状が膿性や粘膿性でないもの すなわち感染が明らかでないものをアレルギー性副鼻腔 炎として種々の治療に関する検討を行った。その結果, 肥満細胞からのヒスタミンやロイコトリエン拮抗剤や遊 離抑制剂だけでなく，好酸球や好中球など炎症細胞の浸 潤抑制作用とケミカルメデイエーター遊離抑制作用も併 せ持つ抗アレルギー剤の使用が有効なことが示唆され， 成人では局所抗アレルギー剂や局所ステロイド剂といっ た局所用薬剤の併用，あるいは副鼻腔炎治療用カテーテ ルなどによる副鼻腔内直接薬液併用が有用な方法である と考えられた。この際, 副鼻腔貯留液中の好酸球や IL-5, RANTES は治療後減少し (図 $1 \sim 3$ ), ・ GM-CSF は改善例で有意に減少していた。一方，小児においても 局所ステロイド剤を併用した群の改善率は, 併用しない 場合に比べそれぞれ改善率が高い傾向にあり，アレルギ 一性副鼻腔炎に対して局所ステロイド剤は効果的に働く と考えられる。しかし, マクロライド剤内服を併用した 


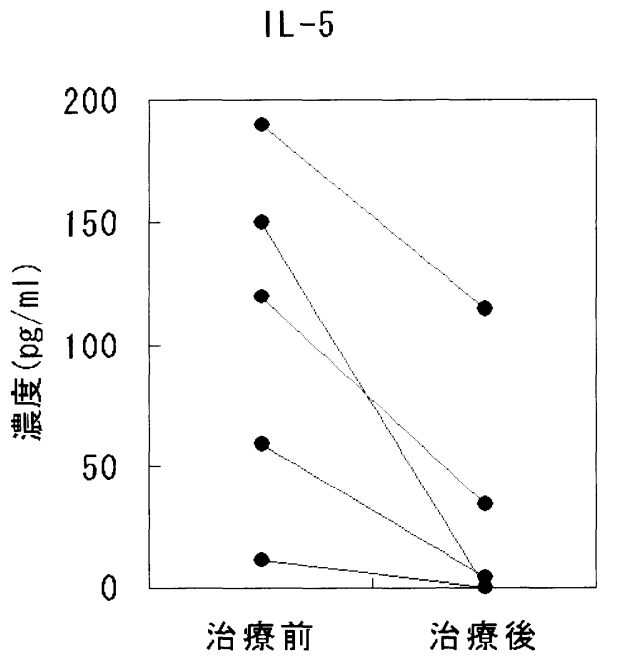

図 1 アレルギー性副鼻腔炎に対して副鼻腔炎治療用カテ ーテルを用いて局所ステロイド剤を注入して治療を 行った前後の副鼻腔眝留液中の IL-5 濃度。治療後, IL-5 濃度は低下している。

\section{RANTES}

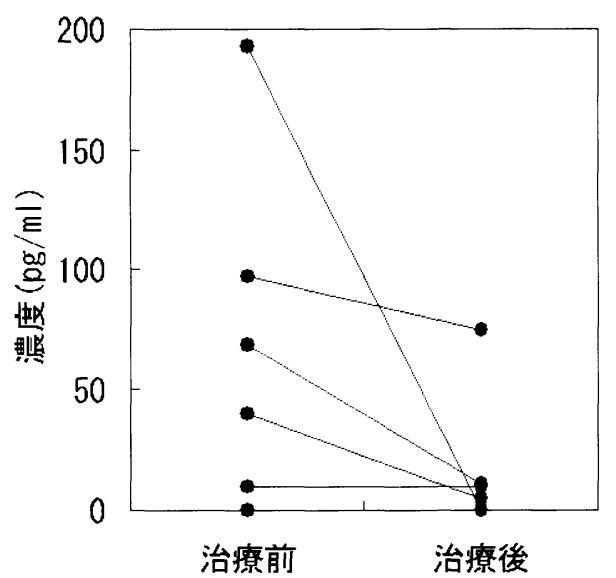

図 2 アレルギー性副鼻腔炎に対して副鼻腔炎治療用カテ ーテルを用いて局所ステロイド剤を注入して治療を 行った前後の副鼻腔貯留液中の RANTES 濃度。治 療後, RANTE 濃度は低下している。

群の改善率は，併用しない場合と比べほとんど変わらな い。このことはマクロライド剤はアレルギー性副鼻腔炎 に効果的でないことを示唆している。また，幼少児の方 が成人より同じ治療による改善率が高い傾向にある。成 人のアレルギー性副鼻腔炎では炎症が持続, 遷延化し, 治療に反応しにくいと推測される。小学生までの幼少児 では，年長者あるいは成人と比べ，これら治療により副 鼻腔陰影が改善されやすく, 炎症の遷延化が軽度である と考えられ，可能な限り早期に治療を開始することも重 要である。

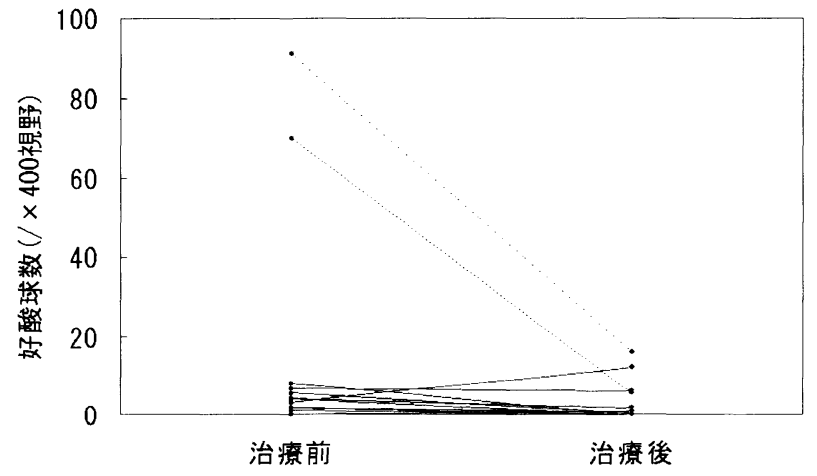

図３アレルギー性副鼻腔炎に対して副鼻腔炎治療用カテ ーテルを用いて局所ステロイド剤を注入して治療を 行った前後の副鼻腔貯留液中の好酸球数。治療後, 好酸球数は低下している。

表 1 慢性副鼻腔炎の内視鏡下鼻内手術成績

\begin{tabular}{|c|c|c|c|c|c|}
\hline 合併症 & 治癒 & 軽快 & 不変 & 計 & 軽快以上 \\
\hline $\mathrm{NA}(-)$ & 11 & 13 & 2 & 26 & $92^{\circ} \%$ \\
$\mathrm{NA}(+)$ & 5 & 8 & 0 & 13 & $100^{\circ} \%$ \\
\hline
\end{tabular}

NA:アレルギ一性鼻炎

以上の保存的治療結果から, 本症の病因に I 型アレル ギーが関わっていることが示唆されたと言える。

\section{3. 内視鏡下鼻内手術の影響}

鼻茸がなくアレルギー性鼻炎症状が主であるいわゆる 狭義のアレルギー性副鼻腔炎に対する手術治療は通常行 わないので，これら症例に対する手術の影響は検討でき ない。しかし, 今回好酸球が鼻汁中や組織中に明らかに 多いアレルギー性鼻炎合併副鼻腔炎いわゆる広義のアレ ルギー性副鼻腔炎に対して内視鏡下鼻内手術を行った場 合の治療成績について検討した。その結果, 術前後の副 鼻腔 C Tでみた炎症の改善度は, アレルギー性鼻炎の合 併の有無と関係なく良好であった（図 4$)$ 。

\section{おわりに}

以上のことより，アレルギー性副鼻腔炎における好酸 球の役割については以下のように考察された。副鼻腔が 通常の状態，すなわち半閉鎖腔である場合には種々の程 度にアレルギー性炎症として影響し副鼻腔陰影を生じさ せる。しかし，内視鏡下鼻内手術により自然口が大きく 開放された場合副鼻腔は半閉鎖腔から開放腔となり，好 酸球の影響はごく軽微であり副鼻腔陰影として現れるほ どではないと思われる。 


\title{
鼻茸における好酸球浸潤の機序について
}

\author{
日本医科大学耳鼻咽喉科学教室 \\ 野中学, Rawankar Ruby, 福元 晃, \\ 荻原望, 酒主敦子, 八木聰明
}

\section{はじめに}

慢性副鼻腔炎の副鼻腔粘膜や鼻茸の病理組織学的特徴 は，浮腫と好酸球浸潤である!.2。この浮腫や好酸球浸澗 がなぜ起こるのか不明な点が多い。一般に炎症が起こる と, まず浮腫形成が起こり, 炎症の慢性化に伴い線維化 へと誘導される。線維化への誘導が起こらないと浮腫形 成がより顕著になると考えられる。臨床的経験からも， 鼻・副鼻腔粘膜において慢性の炎症を起した場合, 線維 化を抢こした病変をみることは非常に少ない。今回鼻・ 副鼻腔では，なぜ線維化が起こりにくいか，また慢性副 鼻腔炎の病態形成に重要と考えられる菌体刺激により線 維芽細胞から好酸球浸潤に重要な因子の産生が起こるか どうか, 鼻・副鼻腔線維芽細胞を用いて検討した。鼻 · 副鼻腔線維芽細胞の特性をみるために, 鼻・副鼻腔線維 芽細胞と肺線維芽細胞とを比較しながら実験を行った。

線維芽細胞が線維化へ誘導する場合, 笳線維芽細胞 [smooth muscle $\alpha$-actin（SMA）陽性線維芽細胞］に变 化する。この筋線維芽細胞はコラーゲンを始めとする細 胞外基質を盛んに作り線維化が抢こる”。線維芽細胞を 線維化への誘導に最も重要と考えられている $\mathrm{TGF}-\beta_{1}$ で 刺激し, 線維芽細胞に扔けるSMA の誘導が起こるか, 細胞外基質の代表である procollagen type Iの産生が起 こるかを検討した。さらに浮腫形成に関与する Vascular endothelial growth factor (VEGF) の産生が起こるか検 討した。

鼻・副鼻腔粘膜においては, アレルギー性副鼻腔炎の ように細菌感染とアレルギー反応がしばしば混在する。 この場合, 鼻・副鼻腔粘膜には好酸球浸潤が多くみられ る。好酸球性炎症を誘導するために重要な因子には, eotaxin や TARC がある。線維芽細胞をグラム陰性菌の菌 体である Lipopolysaccharicle (LPS), Th2 型サイトカイ ンの代表であるIL-4 で刺激し, eotaxin と TARC を産生 を検討した。

\section{方法と対象}

線維芽細胞の単離及び刺激法
線維芽細胞の単離，培養はすでに確立された方法によ り行っだ。単離した線維芽細胞の継代培養を行ない, 実験には第 4 から第10継代の細胞を使用した。健常な 鼻・副鼻腔粘膜として, 第一基板（鈎状突起）加第二 基板（穊骨胞）上の粘膜（ $\mathrm{n}=6$ ）を用いた。

炎症を伴った鼻・副鼻腔粘膜として鼻茸 $(n=6)$ を 用いた。対照として健常な肺組織 $(n=6)$, 線維化肺 $(n=6)$ からの線維芽細胞を用いた。今回使用した組織 は，薬物治療をほどこされていなかった。線維芽細胞は 使用するまで液体窒素の中に保存した。

線維芽細胞の刺激には，TGF- $\beta$,を用いた。培養液は, ペニシリン; $100 \mathrm{U} / \mathrm{ml}$, ストレプトマイシン； $100 \mu \mathrm{g} / \mathrm{ml}$ ， アンフォテリシン B $; 2.5 \mu \mathrm{g} / \mathrm{ml}$ 添加培養液 [Dulbeco's modified Eagle medium (MEM ; Grand Island Biological Co.)]を使用した。

実験 1 : 鼻・副鼻腔線維芽細胞における線維化に重要 な因子の誘導

\section{A) SMAの誘導}

線維芽細胞の培養を, four-well Lab-Tek chamber slicle 上で 4500 cells $/ \mathrm{cm}^{2}$ の細胞数で, 開始した。培養 開始 1 日後に, FBS 濃度を0.4\%にした。実験中, FBS 濃度は $0.4 \%$ に保った。培養開始 2 日後より，1 日㧤き に 3 回 TGF- $\beta_{1}(8,40,200,10 \mathrm{pg} / \mathrm{ml})$ にて線維芽細 胞を刺激した。 3 回目の刺激後 2 日目に培養線維芽細胞 をPLP固定した。免疫組織化学にて筋線維芽細胞の指 標となるSMAを染色した。SMA mRNAの検討には, 線維芽細胞を直径 $100 \mathrm{~mm}$ の培養血で培養し, confluence の状態で24時間 TGF- $\beta_{1}$ で刺激した。刺激後, RT-PCR 法を用いSMA mRNAの検出を行った。

\section{B) Procollagen type I の誘導}

Procollagen type I 産生の検討には, 線維芽細胞を直 径 $100 \mathrm{~mm}$ の培養皿で培養し, confluence の状態で24時 間 TGF- $\beta_{1}$ で刺激した。刺激後 ELISAにて培養液中に 遊離された Procollagen type I を測定し，培盖線維芽細 胞より, RT-PCR 法にて Procollagen type I mRNAの検 出を行った。

C) VEGF の誘導 
VEGF 産生の検討には, 線維芽細胞を直径 $100 \mathrm{~mm}$ の 培養血で培養し, confluence の状態で24時間 TGF- $\beta_{1}$ で 刺激した。刺激後 ELISA（R \& D 社）にて培養液中に 遊離された VEGFを測定し，培養線維芽細胞より， RTPCR 法にて VEGF mRNAの検出を行った。

実験 2 : 鼻・副鼻腔線維芽細胞からの好酸球浸潤に重 要な因子の産生

A ) Eotaxin の誘導

eotaxin 産生の検討には，線維芽細胞を直径 $100 \mathrm{~mm}$ の培養血で培養し, confluence の状態で LPS 単独, IL-4 単独，LPS + IL-4 で刺激した。培養液中にFBSを $10 \%$ 添加した。刺激後 ELISA（R\&D社）にて培養液中に 遊離された eotaxin を測定し，培養線維芽細胞より，RTPCR 法にて eotaxin mRNAの検出を行った。

B ) TARC の誘導

TARC 産生の検討には, 線維芽細胞を直径 $100 \mathrm{~mm}$ の 培養㿼で培養し, confluence の状態でLPS 単独, IL-4 単独，LPS + IL-4 で刺激した。培養液中に FBSを $10 \%$ 添加した。刺激後 ELISA（R\&D社）にて培養液中に 遊離された TARC を測定し，培養線維芽細胞より， RTPCR 法にて TARC mRNAの検出を行った。

\section{結 果}

実騃 $1 ： T(\mathrm{GF}-\beta$, 刺激により，健常な肺の線維芽細胞 におけるSMAの表出は増加した。一方, 健常な鼻・副

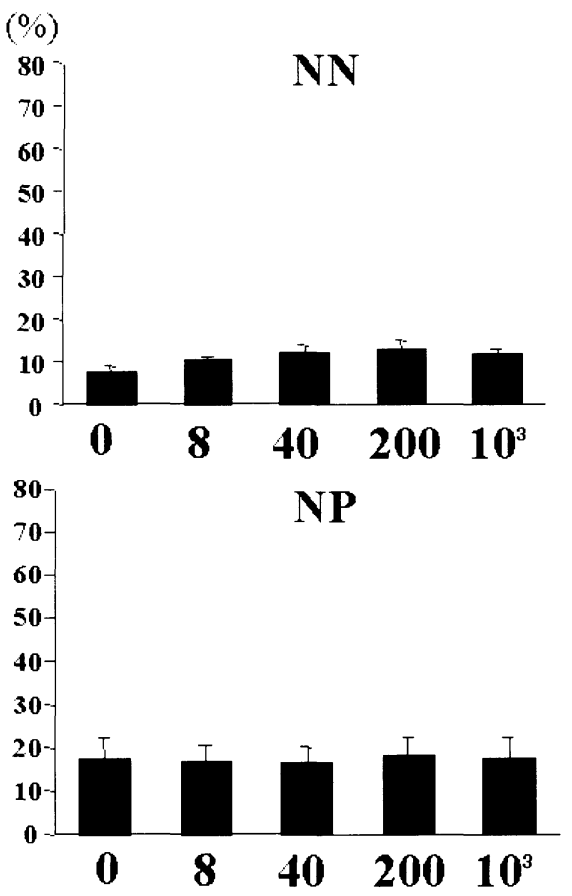

鼻腔粘膜の線維芽細胞におけるSMAの表出は変化しな かった (困)。このSMAに関する鼻・副鼻腔粘膜線維 芽細胞と肺線維芽細胞の違いは, 鼻茸の線維芽細胞と線 維化肺の線維芽細胞の間でも認められた。TGF- $\beta$, 刺激 による procollagen type Iの産生は, 肺線維芽細胞でみ られたが, 鼻・副鼻腔線維芽細胞ではみられなかった。 TGF- $\beta_{1}$ 刺激によるVEGF 産生は, 鼻・副鼻腔粘膜の線 維芽細胞でも，肺の線維芽細胞でも同様に認められた。

実験 2 ：鼻・副鼻腔の線維芽細胞を, LPS で刺激する と微量の eotaxin が産生された。TARCは産生されなか つた。IL-4で刺激すると eotaxinは産生されたが, TARC は産生されなかった。さらにLPS と IL-4の同時 刺激を行うと eotaxinの相乗的産生と TARC の産生が認 められた。これら産生は, LPS と IL-4の量依存的, 刺 激時間依存的に認められた。

考察

筋線維芽細胞は, 線維芽細胞と平滑筋の中間の性質を 持った細胞であり肉芽組織中に初めて発見されだ。コ ラーゲンを始めとする細胞外基質の産生が盛んで線維化 の過程に寄与すると考えられている。笳線維芽細胞は, 正常に治癒した痏痕では消失するが, 種々の臓器の線維 化を起しつつある部位に存在している゙-8。最近，筋線 維芽細胞が, 喘息, 肺線維症など気道の慢性炎症性病変 において，存在することが報告されている゙ッ。

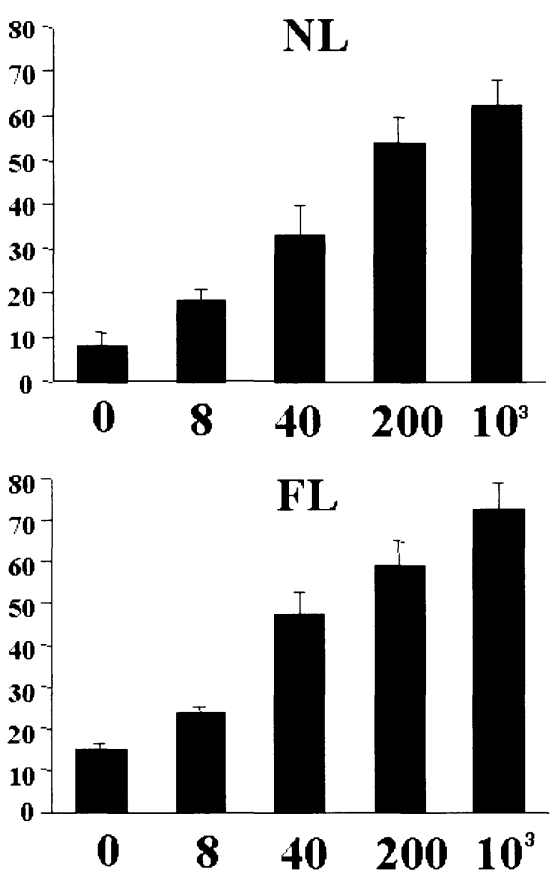

図 線維芽細胞における smooth muscle $\alpha$-actin の誘導 縦軸は線維芽細胞に抢ける筋線維芽細胞の比率 $(\%)$ を示す。横軸は $\mathrm{T}\left(\mathrm{GF}-\beta_{1}\right.$ の量 $(\mathrm{pg} / \mathrm{ml})$ を示す。 $\mathrm{NN}$; 健常な鼻・ 副鼻腔粘膜の線維芽細胞, NP；鼻茸の線維芽細胞, NL；健常な肺の線維芽細胞, FL；線維化肺の線維芽細胞 
TGF- $\beta$ は, 気道の慢性炎症における線維化を誘導亦 る最も重要なサイトカインと考えられている。TGF- $\beta$ で 種々の線維芽細胞を刺激すると, 線維芽細胞は筋線維芽 細胞に変化し，コラーゲンを始めとする細胞外基質産生 が誘導される゙”。肺の線維芽細胞は TGF- $\beta$,で筋線維芽 細胞に変換させることができたが, 鼻・副鼻腔の線維芽 細胞は筋線維芽細胞に変化させることができなかった。 $\mathrm{TGF}-\beta_{1}$ による筋線維芽細胞の誘導が健常の鼻・副鼻腔 粘膜からの線維芽細胞でもできなかったことは, 炎症を 起こす前から鼻・副鼻腔の持つ特有の性質であることを 示している。このことは, 鼻における線維芽細胞は, 他 の線維芽細胞と異なり特殊で, TGF- $\beta_{1}$ 刺激に対する細 胞外基質産生能が劣っていることを示唆している。そこ で, procollagen type Iの産生がどうかを検討した。序 想どうり, 肺の線維芽細胞では, procollagen type Iの 産生が TGF- $\beta_{1}$ で起こったが, 鼻・副鼻腔の線維芽細胞 では起こらなかった。したがって, 肺では, TGF- $\beta$,で刺 激されると線維芽細胞は筋線維芽細胞に変換し, 筇線維 芽細胞は procollagen type Iを産生するが, 鼻・副鼻腔 の線維芽細胞は, 筋線維芽細胞に変換しないので procollagen 産生が起こらない, と考えられる。以上の結果よ り, 鼻腔においては炎症により TGF- $\beta$ が局所で産生さ れ, 線維芽細胞に作用した場合に, 細胞外基質産生が起 こりにくいため, 結果として浮腫形成が顕著になると考 えられる。一方, VEGF 産生は TGF- $\beta_{1}$ 刺激で, 鼻・副 鼻腔の線維芽細胞でも肺の線維芽細胞でも同様にみられ たことは, 鼻・副鼻腔の線維芽細胞に TGF- $\beta$ のレセプ ターが欠如しているのではなく, 刺激の細胞内伝達に㧍 いて肺の線維芽細胞と違いがあると考えられる。

近年, 線維芽細胞は eotaxin を始めとするケモカイン を産生することが解り，好酸球遊走に関して重要な役割 を果たしていると考えられている!"”。特に, eotaxin 産 生能は非常に高く, 主な産生細胞と考えられている゙”。

TARC は, Th2 細胞の遊走因子で，これまで上皮細胞が 主な産生細胞と考えられている。TARC が炎症局所で産 生されると, Th2 細胞が遊走し, Th2 サイトカインが炎 症局所に増加し, 結果として好酸球浸潤が誘導される。 したがって eotaxin と同様にTARC も好酸球浸潤に重要 である。今回の我々の検討から, 菌体 (LPS) と Th2 型 サイトカインである IL-4 の同時刺激で eotaxin の相乗 的産生と TARCの産生が確認された。この eotaxin と TARC 産生には血清の存在が必要で, 血清中に含まれる LBP (Lipopolysaccharide Binding Protein) や sCD 14 (soluble CD14) が重要な役割を果たす。鼻・副鼻腔に おいては, 線維化を起こしにくいという特性がある。こ
の特性が浮腫を顕著にさせ, 血管から LBP や SCD14 が 粘膜の間質に漏出し線維芽細胞が菌体に鋭敏に反応し, eotaxin と TARC 産生を介して好酸球浸潤を誘導してい ると考えられる。

\section{参考文献}

$1)$ Cauna H, Hinderer KH, et al: Fine structure of nasal polyps. Ann. Otol. Rhinol. Laryngol. 81: 4158, 1972.

2) Kakoi H, Hiraide F : Histological study of formation and growth of nasal polyps. Acta Otolaryngol. 103 : 137-144, 1987.

3 ) Schmitt-Graff A, Desmouliere A, et al : Heterogeneity of myofibroblast phenotypic features: an example of fibroblastic cell plasticity. Virchows Archiv. 425 : 3-24, 1994.

4) Jordana M, Schulman J, et al: Heterogeneous proliferative characteristics of human adult lung fibroblast lines and clonally derived fibroblasts from control and fibrotic tissue. Am. Rev. Respir. Dis. 137 : 579-584, 1987.

5 ) Gabbiani G, Ryan GB, et al: Presence of modified fibroblasts in granulation tissue and their possible role in wound contaction. Experientia 27 : 548-550. 1971.

6) Holopainen E: Budlesonide in the treatment of nasal polyps. Eur. J. Respir. Dis. 63 (Suppl 122) : 221-228, 1982.

7 ) Dvorak H F : Tumors: wouns that do not heal. Similarities between tumor stroma generation and wound healing. N. Engl. J. Med. 315 : 1650-1659, 1986.

8 ) Sappino AP, Schurch W, Gabbiani G: Differentiation repertoire of fibroblastic cells : expression of cytoskeletal proteins as marker of phenotypic modulations. Lab. Invest. 63 : 144-161, 1990.

9 ) Toft A: Double-blind comparison between beclomethasone dipropionate as aerosol and as powder in patients with nasal polyposis. Clin. Allergy 12 : 391-401, 1982.

10) Bartels J, Schluter $C$, et al: Human dermal fibroblasts express eotaxin : molecular cloning, mRNA expression, and identification of eotaxin sequence variants. Biochem. Biophys. 225: 1045-1051, 1996. 


\title{
好酸球におけるアポトーシスとその制御
}

\author{
札沅医科大学医学部耳鼻咽诶科学教室 \\ 白 崎 英明, 渡邊一正, 水見徹夫
}

\section{はじめに}

鼻副鼻腔疾患における局所好酸球増多は, アレルギー 性鼻炎やアスピリン喘息に合併する鼻咠で著しい。好酸 球を制御することは，これらの疾患の治療に大変有用で あると思われる。局所ステロイド剤はこれらの疾患の治 療法として古くから行われているが, 試騃管内で直接好 酸球のアポトーシスを引き起こすことが報告されてい る'。一方, ステロイド剤のみならず, 最近鼻アレルギ 一に使われることが多いロイコトリエン受容体拮抗剤も 局所と末梢血の好酸球数を減少させることが知られてい る。本シンポジウムでは, これら日常臨床に用いられる 薬剤の好酸球に対するアポトーシス誘導作用について, 我々の研究結果を中心に概説する。

\section{1）ステロイド剤による好酸球のアポトーシス誘導}

1局所ステロイド剤による鼻茸組織内好酸球アポトー シス誘導作用。

両側の鼻茸患者を対象とし, 鼻茸切除術24時間前から 一側のみフルチカゾン点鼻を行ない, 切除された鼻茸中 好酸球のアポトーシスの程度を, TUNEL 法と抗 EG2 抗 体による二重染色を行い評価した。フルチカゾン点鼻を 行った側の鼻茸では, 好酸球の TUNEL 陽性率がコント ロールと比べて有意に高い結果が得られた。この事よ り, 日常臨床に用いられる薬郕の通常量の投与により好 酸球のアポトーシスが誘導されることが明らかとなっ た。さらに，in vitroにおける同様なステロイド用の効 果を, 細片された鼻茸を用いて行った。In vitroの実験 では，ステロイド剤はデキサメサゾンを用いたが，in vivoの研究と同様に，ステロイド剤により組織中好酸球 の TUNEL 陽性率が増加した。このように，ステロイド 扸によって, 鼻茸組織中の好酸球のアポトーシスが誘導 されることが確認された。前述したように，ステロイド 剂は, 試験管内で直接好酸球のアポトーシスを引き起こ すことが報告されているが，上皮細胞からの GM-CSF などの生存延長因子の産生抑制による機序も考えられる ため，培養上皮細胞を用いて以下の実験を行った。

2 ステロイド剤による培養上皮細胞からの GM-CSF 産生抑制
末梢血から分離した好酸球を MTT アッセイにて評価 すると, 鼻茸由来初代培養上皮細胞の培養上清の添加に より，好酸球の生存が延長されることを確認している。 この作用は，抗 GM-CSF 抗体により中和されるため, 上皮細胞から産生される GM-CSF が局所好酸球の生存 に重要な役割を果たしている事が推察される。このた め, ステロイド剤が, 培養上皮細胞からの GM-CSF 産 生を抑制するかどうかを検討した。手術で得られた鼻咠 にプロテアーゼ処置して, 上皮細胞を分離し初代培養し た。サブコンフルエントになった時点で, デキサメサゾ ンを添加し, 経時的に培養上清中の GM-CSF 濃度を ELISA キットにて測定した。このようにして検討した 結果, デキサメサゾンにより上皮細胞からの GM-CSF 産生は著明に抑制されることが確認された。

以上の結果からステロイド剂の好酸球のアポトーシス 誘導作用には，直接作用以外に上皮細胞からの GM-CSF 産生抑制を介した作用が関係していると思われる。次 に，ロイコトリエンに関する研究成果について述べる。

2）CysLT1 受容体拮抗刜による好酸球アポトーシスの 誘導

本邦においては，2000年にCysLT1 受容体拮抗郕であ るプランルカストが，アレルギー性鼻炎に対して保険適 応となり広く臨床に用いられているが, この薬郕を投与 すると局所と末梢血の好酸球数が減少することが認めら れる。この好酸球数の減少は,この薬郕により好酸球の アポトーシスが誘導されている事に起因する可能性が考 えられるここの CysLT1 受容体拮抗剤による好酸球アポ トーシスにつては2000年にLee らがSKF104353という CysLT1 受容体拮抗剤を用いた研究を報告している”。 そこで，今回我々は，プランルカストを用いてLeeら の報告の追試を行った。アレルギー性鼻炎患者 3 名から

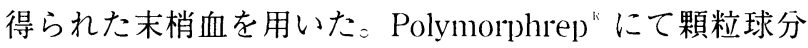
離し，磁気ビーズ（MACS）にてCD16+細胞をディプ リーションし, 純度 $95 \%$ 以上の好酸球と分離した。分離 された好酸球を RPIM-1640に懸濁し，48穴プレートに て16一40時間培養したここの系に対し, LTD4 10"”〜10 M，CysLT1 受容体拮抗剤であるプランルカスト $10^{-\infty}$ $10^{-5} \mathrm{M}$ を添加して好酸球の生存とアポトーシスに対する 


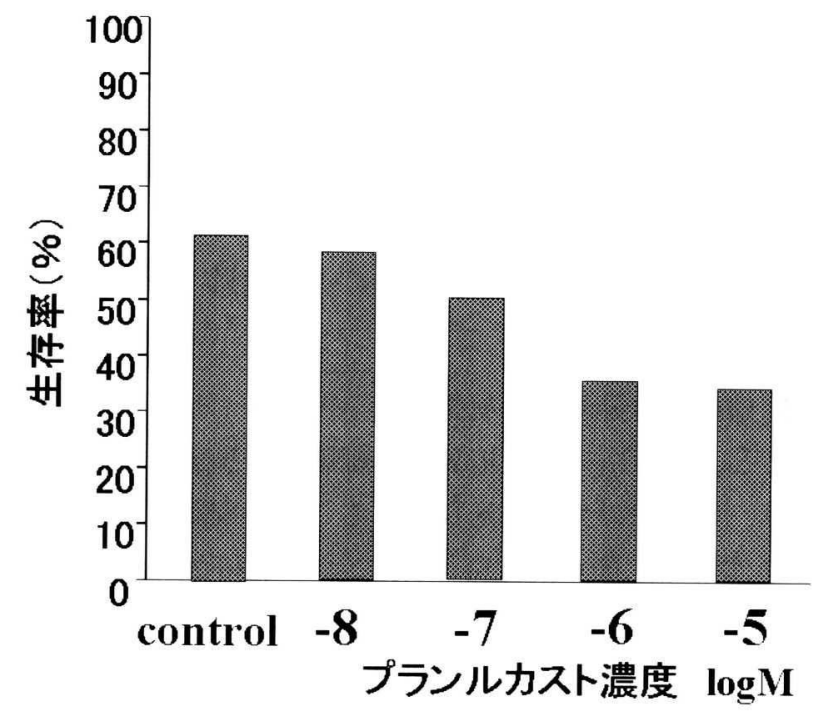

図 1 培盖40時間後の好酸球の牛存率

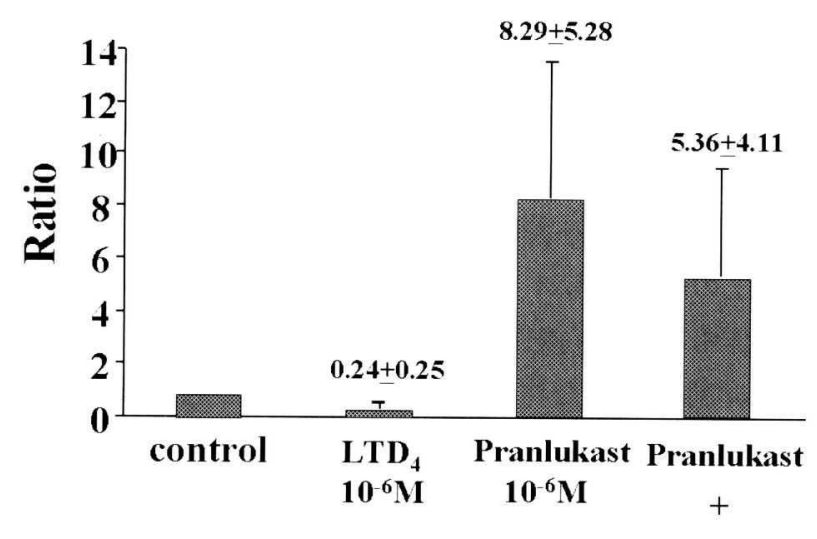

$\mathrm{LTD}_{4}$

図 2 培養40時間後の好酸球細胞質分画内スクレオソーム 濃度。コントロールに刘する比で示した。 $N=3$

影響を検討した。細胞死の評価は, トリパンブルー細胞 分染法により生細胞数を，アポトーシスにより増加する 細胞分画内のモノー, オリゴエンドヌクレオソーム量を 細胞死検出 ELISA キット（ロッシュ・ダイアグノステ ックス社）にて測定した。結果として，3 人から分離さ れた好酸球は同様な傾向を示し, LTD4により濃度依存 性に生細胞数は増加した。一方，プランルカストにより 濃度依存性に好酸球の生細胞数が低下した（図１）。細 胞分画内のエンドヌクレオソームについてもトリパンブ ルーの結果を毫付けるものであり，LTD4により，エン

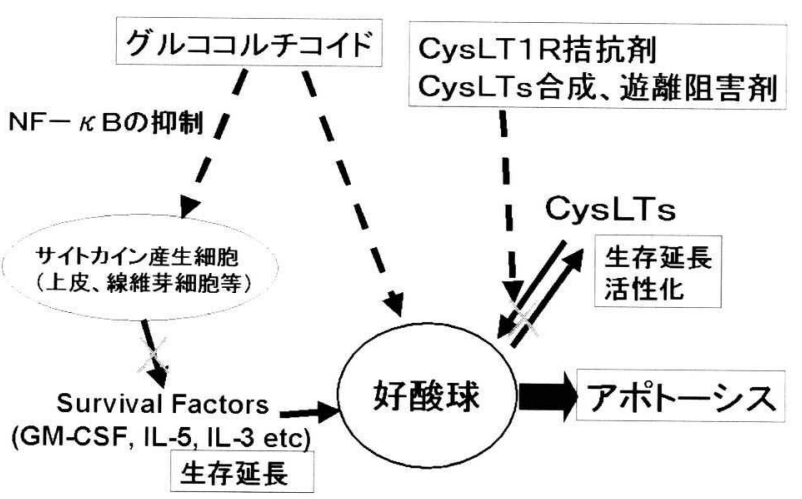

図 3 結果のまとめ

CysLT1受容体怙抗剂と局所ステロイド剂により好 酸球のアポトーシスが引き起こる事を示す。点線は 抑制。

ドヌクレオソームは低下し，プランルカストにより著明 な増加を認めた（四 2 ）。以上の結果より，プランルカ ストは直接的に好酸球のアポトーシスを誘導し,さら に, 局所で産生される LTI)4による好酸球生存延長作用 をも抑制することにより，局所と全身の eosinophiliaに 有効であることが示唆された。

\section{まとめ(四 3 )}

耳鼻咽喉領域における好酸球が関与する疾患として は，アレルギー性鼻炎が代表的であるが，それ以外に鼻 革（特にアスピリン喘息に伴うもの），好酸球増多性鼻 炎, 好酸球性中耳炎などがある。ステロイド剤と CysLT1 受容体拮抗剤は, 好酸球のアポトーシス誘導作 用を介して，これらの好酸球性炎症の制御に有用である と考えられる。

\section{参考文献}

1) Meagher LC, Cousin JM, Seckl JR, et al: Opposing effects of glucocorticoids on the rate of apoptosis in neutrophilic and eosinophilic granulocytes. J Immunol. 156 : 4422-4428, 1996.

2 ) Lee E, Robertson T, Smith J, et al: Leukotriene receptor antagonists and synthesis inhibitors reverse survival in eosinophils of asthmatic individuals. Am J Respir Crit Care Med 161: 1881-1886, 2000. 